\title{
車臷情報システムにおける階層メニューの操作性 ーボタンと文字の大きさの影檽一
}

○伊藤英明（名城大学・学生）、池村澄男、石原荘一（名城大学）

Maneuverability of Hierarchical Menu-driven Vehicle

-Effect of Size of Button and Letter-

Hideaki Ito (Student of Meijo University),Sumio Ikemura,Soichi Ishihara(Meijo University)

\section{1. はじめに}

近年、車載情報機器の多機能・高機能化が進ん でいるのに伴って、これらを操作することが原因 となる交通事故や運転ミス等も考えられる。

機能が増大寸る車載情報機器において操作性を 良くすることは、利便性, 安全性の面で重要である。 そこで、運転中における車載情報機器の操作が人間 に与える影響として大きなものであると考え、階層 メニューの操作ボタン形状や文字の大きさ、その比 率を変えて操作性一の影響を比較・検討寸る。そし て安全性や操作性について総合的に優れたボタン 形状を導き出す。

\section{2. 実験の概要}

本実験では、階層メニューの操作ボタンの形状や 文字の大きさ、その比率を変えた階層メニューを使 用して、2項目6階層、4項目3階層、8項目2階層（以 下2^6，4^3，8^2）の61個の最終項目から1個を選択 する運転中における操作実験を実施する。

\section{1 実験方法}

1) 被験者は普通自動車免許を持つ 20 代男性 6 名。

2)タッチパネル型パソコンを車載情報機器とし、

ダッシュボード中央に配置した。

3) コンピュータ音声による操作指示で被験者に階

層メニューを操作させた。

4) 前方視界は焦点調節効果を考慮し、被験者から

$3 \mathrm{~m}$ 離孔た 100 インチスクリーン上に投影した。

5) 速度は $90 \mathrm{~km} / \mathrm{h}$ として、運転中は操作することよ

りも目標範囲をキープすることを優先させた。

6) 実験は 10 問(250s) とし、各階層メニューについ て実施した。

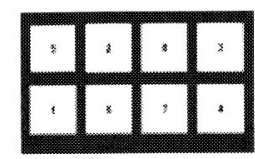

基淮モデル

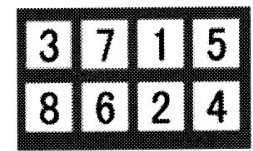

96 ポイント

\section{$7 \longdiv { 3 } \longdiv { 6 } 2$

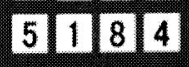

\section{3. 実施内容}

本実験にて使用したボタン形状を図 1 に示す。

a) ボタンの大きさ大で文字の大きさが 24 ポイン トの基淮モデル。(ボタンと文字の割合 29\%)

b) ボタンの大きさ大で文字の大きさが 96 ポイン トのもの。(ボタンと文字の割合 93\%)

c) ボタンと文字の割合を 93\%一定として、ボタン の大きさを小さくしたもの。文字の大きさ $77,58,38,24$ ポイントの 4 種類

4. 実験の結果 $\left[\begin{array}{ccc}\mathrm{t} \text { 検定 } & * & \alpha<0.05 \\ \text { 4. 有意差 } & * * & \alpha<0.01 \\ \mathrm{NS} & \text { 有意差なし }\end{array}\right)$

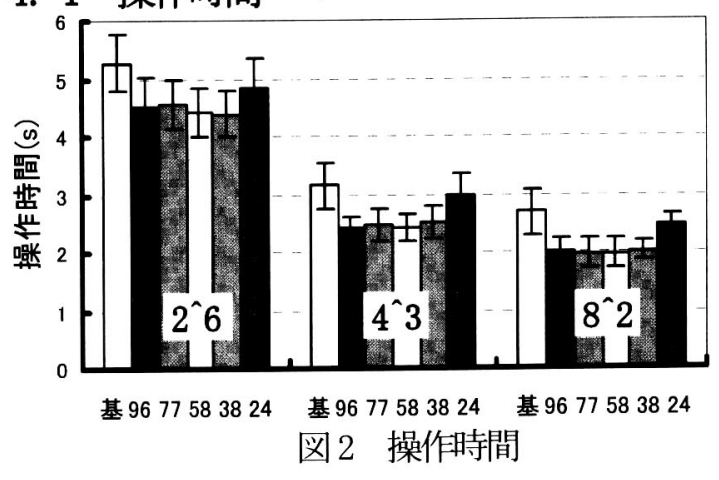

表 1 操作時間の $\mathrm{t}$ 検定の結果

\begin{tabular}{|c||c|c|c|c|c|}
\hline \multirow{2}{*}{$2 \wedge 6$} & & 96 & 77 & 58 & 38 \\
\cline { 2 - 6 } & 基準 & $*$ & $*$ & $* *$ & $* *$ \\
\hline \hline \multirow{2}{*}{4 3 } & 基準 & $* *$ & $* *$ & $* *$ & $* *$ \\
\cline { 2 - 6 } & 24 & $*$ & $*$ & $*$ & $*$ \\
\hline \hline \multirow{2}{*}{8 82 } & 基準 & $* *$ & $* *$ & $* *$ & $* *$ \\
\cline { 2 - 6 } & 24 & $* *$ & $* *$ & $* *$ & $* *$ \\
\hline
\end{tabular}

2^6，4^3，8^2の全てにおいて、基淮モデルお よび 24 ポイントと比較して、96 ポイントから 38 ポイント 4 種類の操作時間が短縮されている。

\section{7 362 4}

58 ポイント

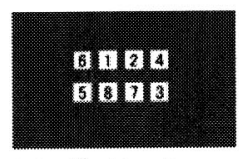

38 ポイント

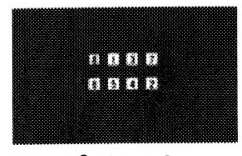

24 ポイント
図 1 ボタン形状 


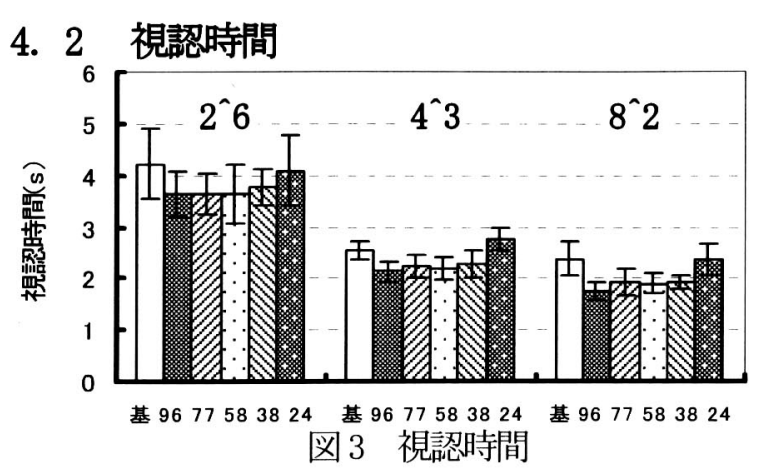

表 2 視認時間の $\mathbf{t}$ 検定の結果

\begin{tabular}{|c||c|c|c|c|c|}
\hline \multirow{2}{*}{4 43 } & & 96 & 77 & 58 & 38 \\
\cline { 2 - 6 } & 基準 & $* *$ & $*$ & $*$ & NS \\
\cline { 2 - 6 } & 24 & $* *$ & $* *$ & $* *$ & $* *$ \\
\hline \hline \multirow{2}{*}{$8 \wedge 2$} & 基準 & $* *$ & $*$ & $*$ & $*$ \\
\cline { 2 - 6 } & 24 & $* *$ & $*$ & $* *$ & $* *$ \\
\hline
\end{tabular}

2^6，4^3，8^2の全てにおいて、基準モデルおよ び24ポイントと比較して、96ポイントから38ポイン 卜4種類の視認時間が短縮されている。

4. 3 視認回数

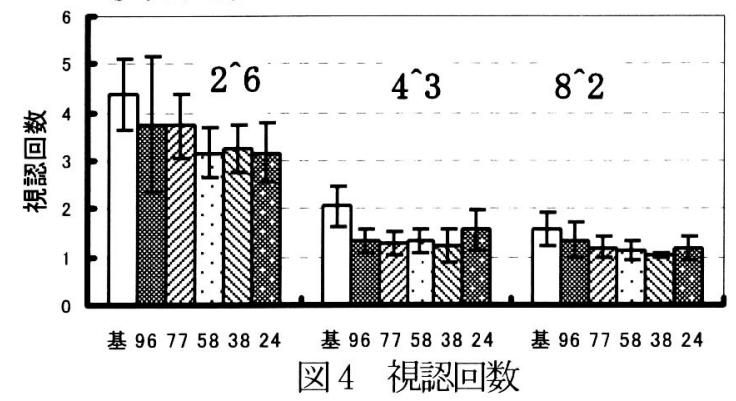

表 3 視認回数の $\mathrm{t}$ 検定の結果

\begin{tabular}{|c||c|c|c|c|c|}
\hline \multirow{2}{*}{ 2^6 } & & 58 & 38 & 24 & \multirow{2}{*}{} \\
\cline { 2 - 5 } & 基準 & $* *$ & $*$ & $*$ & \\
\hline \hline \multirow{2}{*}{$4 \wedge 3$} & & 96 & 77 & 58 & \multirow{2}{*}{38} \\
\cline { 2 - 5 } & 基準 & $* *$ & $* *$ & $* *$ & $* *$ \\
\hline \hline 8^2 & 基準 & $*$ & $*$ & $* *$ & $* *$ \\
\hline
\end{tabular}

ボタン形状が小さくなるに伴って、視認回数は 減少する傾向であることが分かった。

\section{4 車線逸脱量}

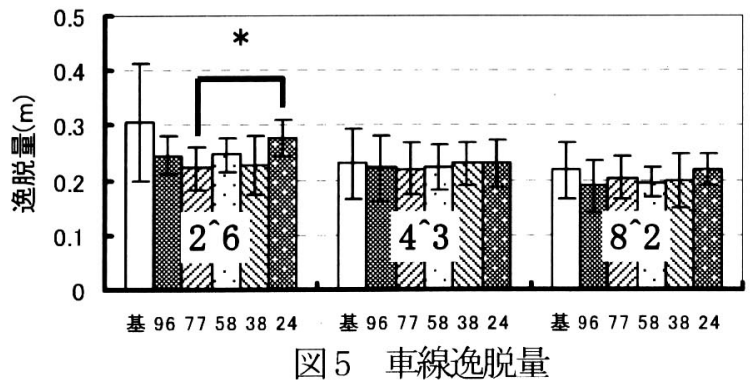

26では基淮モデルと 24 ポイントの車線逸脱量 が大きく、それ以外のものでは有意な差はみられ なかった。

\section{5 NASA-TLX}

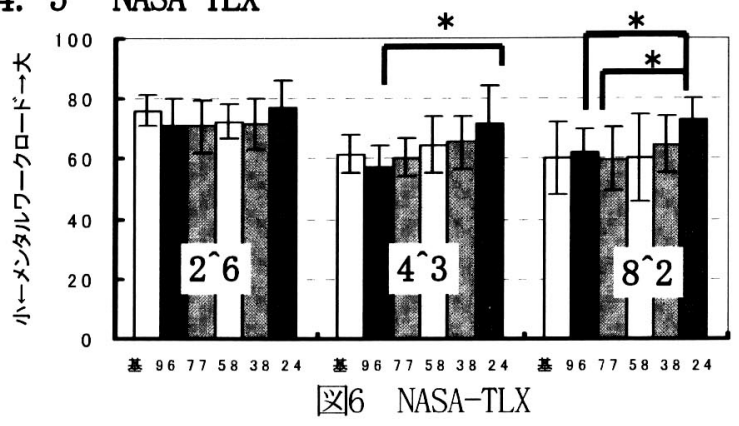

2^6，4^3，8^2の全てにおいて、ボタン形状が 小さくなるに伴って、メンタルワークロードが増 加する傾向であることが分かった。

\section{5.まとめ}

階層メニューの操作ボタン形状や文字の大きさ、 その比率を変えて操作性への影響を比較・検討し た結果以下のような事が分かった。

(1) 操作時間については96、77、58、38 ポイン トの 4 種類が優れていた。

（2）視認時間と視認回数については96、77、58 ポイントの 3 種類が優れていた。

（3）車線逸脱量についてはあまり差がみられな かった。

(4) NASA-TLX によるメンタルワークロードの結

果は、96、77、58 ポイントの 3 種類が優れて いた。また、項目数別については 4`3 と8`2 が優れていた。

以上の結果より、77 ポイントと 58 ポイントの ものが最も優れており、続いて 96 ポイントが総合 的に優れているという結果になった。

\section{参考文献}

1）池村澄男、石原荘、松村大地：車載情報シ ステムにおける階層メニューの操作性につ いて、総合学術論文集、名城大学総合研究所、 №.4 (2005-3) P53-64 